Eskişehir Osmangazi Üniversitesi Mühendislik ve Mimarlık Fakültesi Dergisi 27(2), 116 - 124, 2019
Journal of Engineering and Architecture Faculty of

Eskisehir Osmangazi University 27(2), 116 - 124, 2019

\title{
USING FUZZY TOPSIS AND REGRESSION BASED WEIGHTS TO RANK E-COMMERCE WEBSITES
}

\author{
N. Fırat ÖZKAN ${ }^{1 *}$, Fulya GÖKALP YAVUZ² \\ ${ }^{12}$ Eskişehir Osmangazi University, Department of Industrial Engineering, Eskişehir, TURKEY \\ ORCID No : https://orcid.org/0000-0003-4464-7052 \\ ${ }^{2}$ Middle East Technical University, Department of Statistics, Ankara, TURKEY \\ ORCID No: https://orcid.org/0000-0002-7750-9767
}

\begin{tabular}{l}
\hline Keywords \\
\hline E-Commerce, \\
Website, \\
Fuzzy TOPSIS, \\
Regression, \\
Multicriteria \\
Usability
\end{tabular}

DOI : http://dx.doi.org/10.31796/ogummf.563348

\begin{abstract}
Website usability is a widespread study area which incorporates researches from various disciplines. Several methods are available to evaluate usability of a website. Checklists, heuristic evaluations, expert evaluations, surveys and user tests are presented as the most popular methods for the evaluation of websites. Especially $e$ commerce websites' usability has a critical importance due to the rising in competence and the rising in the number of e-commerce websites. The diversity of e-commerce websites evokes typical example of multi criteria decision making (MCDM) issue in daily life of humanity. Since different user groups have different expectations from the websites, the evaluation method should be structured to include appropriate measurement criteria. The main aim and the target users of the website should be considered attentively while defining the evaluation method. In this study, the most visited (Based on Alexa.com list in January, 2018) e-commerce websites in Turkey are compared in terms of usability. Criteria are decided based on the study which was published by Lee and Kozar (2015). Two different weighting approaches are integrated to TOPSIS method. One of these approaches is fuzzy expert evaluation and the other one is weighted regression estimate. We aim to discover different impressions between e-commerce website designers and users on the same criteria to provide a comprehensive viewpoint.
\end{abstract}

\section{E-TICARET SITTELERININ KARSSILAŞTIRILMASINDA BULANIK TOPSIS VE REGRESYON TEMELLİ AĞIRLIKLANDIRMA KULLANIMI}

\begin{tabular}{l}
\hline Anahtar Kelime \\
\hline E-Ticaret \\
Web Siteleri \\
Bulanık TOPSIS \\
Regresyon \\
Çok Kriterli \\
Kullanılabilirlik
\end{tabular}
Öz

Web sitesi kullanılabilirliği, çeşitli disiplinlerden katkılarla beslenen araştırmaları içeren yaygın bir çalışma alanıdır. Bir web sitesinin kullanılabilirliğini değerlendirmek için çeşitli yöntemler mevcuttur. Kontrol listeleri, sezgisel değerlendirmeler, uzman değerlendirmeleri, anketler ve kullanıcı testleri web sitelerinin değerlendirilmesinde en popüler yöntemler olarak sunulmaktadır. Özellikle e-ticaret web sitelerinin kullanılabilirliği, bu sitelere oluşan rağbet ve e-ticaret web sitelerinin sayısındaki artış nedeniyle kritik bir öneme sahiptir. E-ticaret web sitelerinin çeşitliliği, insanlığın günlük yaşamında çok kriterli karar verme (MCDM) sorununa tipik bir örnek olarak gösterilebilir. Farklı kullanıcı gruplarının web sitelerinden farklı beklentileri olduğundan, değerlendirme yöntemi uygun ölçüm kriterlerini içerecek şekilde yapılandırılmalıdır. Değerlendirme yöntemi tanımlanırken ana amaç ve web sitesinin hedef kullanıcıları dikkatle değerlendirilmelidir. Bu çalışmada, en çok ziyaret edilen (Ocak 2018'de Alexa.com listesine göre), Türkiye'deki e-ticaret web sitelerinin kullanılabilirlik açısından karşılaştırılmıştır. Lee ve Kozar (2015) tarafından önerilen eticaret siteleri kullanılabilirlik ölçütleri kriter olarak dikkate alınmıştır.. TOPSIS yöntemine iki farklı ă̆ırlıklandırma yaklaşımı entegre edilmiştir. Bu yaklaşımlardan biri bulanık uzman değerlendirmesi ve diğeri ağırlıklı regresyon tahminidir. Bu çalışma ile kapsamlı bir bakış açısı sağlamak ve e-ticaret web sitesi tasarımcıları ile kullanıcıları arasında ortak kriterlerdeki farklı izlenimleri keșfetmek amaçlanmıştır.

\footnotetext{
*Sorumlu yazar; e-posta : fozkan@ogu.edu.tr
} 
Eskişehir Osmangazi Üniversitesi Mühendislik ve Mimarlık Fakültesi Dergisi 27(2), 116 - 124, 2019
Journal of Engineering and Architecture Faculty of Eskisehir Osmangazi University 27(2), 116 - 124, 2019

\begin{tabular}{llll}
\hline Araştırma Makalesi & Research Article & \\
Başvuru Tarihi & $: 21.05 .2019$ & Submission Date & $: 21.05 .2019$ \\
Kabul Tarihi & $: 13.07 .2019$ & Accepted Date & $: 13.07 .2019$ \\
\hline
\end{tabular}

\section{Background}

Electronic commerce sites have been studied by many researchers in terms of usability, design features and user expectations. As a result of these studies, some criteria have emerged which are generally accepted among researchers (Lee and Kozar, 2012). However, as in the case of every other area in the changing world, ecommerce needs and expectations are also being updated continuously. Therefore, there may be differences between the developed designs and user opinions from time to time. In other words, usability issues for e-commerce are still existing. These issues can be summarized as incomprehensible content, inconsistent forms and some problems regarding navigation, interaction and reliability (Lee and Kozar, 2012). For this reason, it is a requirement to consider and present evaluation differences between designers and users.

\section{Introduction}

The number of people using e-commerce websites has been naturally increasing. Users do not only utilize these websites for shopping but also for getting information about products or comparing them. Depending on the research of Turkey B2C E-Commerce Report 2016 by yStats.com; internet is used for searching "product and service related information" among more than \%60 of Turkish population and more than $\% 20$ of internet users purchase service or product online. In $2017 ; 24.8 \%$ of all internet users aged 16-74 in Turkey bought products and services online according to Turkish Statistical Institute. There is a growth in e-commerce since these studies finalize and more increasing is expected in ecommerce sales in Turkey, as do in worldwide.

Previous studies about websites usability come forward as an attractive study area. Tracy and Albers (2006) provide a method containing NASA-TLX test, memory test and tapping test to compare websites' usability in terms of cognitive load. De Jong and Lentz (2006) searched municipality websites' usability via a scenario based method. In another study researchers compared usability of four mapping websites using an experimental process including user tests (Nivala, Brewster and Sarjakoski, 2008). Several studies on usability area focus on e-commerce websites specifically. Lee and Koubek (2010) examined usability of nine online bookstores via user test among ten participants. Sivaji, Downe, Mazlan, Soo and Abdullah (2011) studied on importance of fundamental usability and design elements and provided a case study using heuristic evaluations and usability testing with support of eye tracking system. Some researchers in some countries prefer focusing on countrywide e-commerce websites. In one of that kind of studies, six Lithuanian ecommerce websites were compared through user surveys in terms of quality (Davidaviciene and Tolvaisas, 2011). Youngblood and Mackiewicz (2012) studied on municipal government websites' homepages in Alabama (US). They used ten usability features forming a checklist for evaluating the websites. Lee and Kozar (2012) provide a fundamental study which indicates the most important usability elements. Besides these usability studies, some researchers try to compare usability testing methods. Carmona et al. (2012) provided a methodology based on web usage mining to improve one particular website's design. Belanche, Casalo and Guinaliu (2012) researched website usability in terms of consumer satisfaction, intention of use and perceived risk. Goh et al. (2013) performed user tests via an eye tracker to compare four types of usability testing methods (Feedback Capture after Task, Retrospective Think Aloud, Retrospective Think Aloud with Eye Movement and observation). They applied all these methods on a Malaysian online gift shop.

A lot of competitive e-commerce websites are available all around the world. In that respect, it can be called multi criteria decision making (MCDM) that picking the most accomplished website alternative. Multi-criteria decision making methods are strong tools to compare websites and any other products or organizations. Akincilar and Dagdeviren (2014), on the other hand, preferred to use AHP and PROMETHE, one of the multicriteria decision-making methods, while examining the preference of websites. Delice and Güngör (2009) are also among researchers using the AHP method and benefited from the intuitive approach of the experts in weighing the criteria.Technique for Order Preference by Similarity to Ideal Solution (TOPSIS) is one of the most popular tools used by a great deal of researchers in different application areas such as economics, engineering, finance, etc. TOPSIS was firstly suggested by Hwang and Yoon (1981). In TOPSIS technique it is possible to compare $\mathrm{n}$ different alternatives by $\mathrm{m}$ different criteria and it is based on trying the best alternative which is nearest to positive ideal solution and farthest from negative ideal solution (Hwang and Yoon, 1981; Pal and Choudhury, 2009; Zeleny, 1982). This technique has some critical steps such as deciding criteria and weighting of the criteria. The weighting step is subjective and it is the weak point of this technique. However, there are alternative weighting methods to 
Eskişehir Osmangazi Üniversitesi Mühendislik ve Mimarlık Fakültesi Dergisi 27(2), 116 - 124, 2019

make it more consistent and persistence. Using fuzzy sets is one of them to make it stronger. The first introduction of fuzzy sets is made by Zadeh (1965) and Chen (2000) in which TOPSIS is extended into the fuzzy environment to solve multi-criteria decision making problems.

By means of TOPSIS's large application area, lots of researchers use it for different aims in different sectors. Chen, Lin and Huang. (2006) used this technique for comparing suppliers in supply chain management with a fuzzy approach. Huang (2008) provided a study which combined entropy weight and TOPSIS to select an information system. One of the combined application studies for supplier selection was provided by Boran, Genç, Kurt and Akay (2009). The researchers used TOPSIS method with combination of intuitionistic fuzzy set. Another study belongs to Pal and Choudhury (2009) that integrates different method into TOPSIS. In their study TOPSIS is applied with SERVQUAL instrument to compare service qualities of Indian Banks. Guo and Zhang (2010) provided a study containing a stock selection model which is based on Analytic Hierarchy Process (AHP), Factor Analysis and TOPSIS. Yue (2011) provided a study which has a different approach of TOPSIS. In this study an extended approach which based on group decision making was developed. Several studies using TOPSIS for website comparisons are also available. As an example, Sun and Lin (2009) compared two Taiwan e-commerce websites via fuzzy TOPSIS in terms of service quality. In another study e-commerce websites were ranked using AHP and TOPSIS methods (Yu, Guo, Guo and Huang, 2011).

In this study, the most visited e-commerce websites in Turkey are evaluated with the criteria scaled in the ecommerce literature and they are compared through two different approaches of Technique for Order Preference by Similarity to Ideal Solution (TOPSIS) method based on two types/complementary information acquired from experts and website users. In this study, a comparison which is thought to be incomplete, apart from innovations such as expert evaluations in literature, using different criteria and changes in weighting approaches, is aimed. When the websites were evaluated from the perspective of designer and user over the same usability criteria, it was investigated whether there were any changes in the prominent sites.

The rest of the paper is organized as follows. A brief explanation of TOPSIS method steps is located in Section 1. In Section 2, we apply Fuzzy TOPSIS with the weights obtained from two web designer, five academicians who have studies about web site ergonomics and usability. TOPSIS with Weighted Regression Estimates is located in Section 3, following Survey study and descriptive
Journal of Engineering and Architecture Faculty of Eskisehir Osmangazi University 27(2), 116 - 124, 2019

statistics. Some conclusion remarks are presented in Section 4.

\section{Steps of TOPSIS Method}

In this study, generally validated different usability criteria have been taken into account. Therefore, there was a need for a method that can consider all the criteria for evaluation. TOPSIS is a method to compare different alternatives by keeping a variety of criteria on the appropriate scale (Alptekin, Hall and Sevim, 2015). Because of that aspect, it is a useful tool in the area of web site evaluation (Nagpal, Mehrotra, Bhatia and Sharma, 2015). The steps of the method are presented in this section.

Step 1: A decision matrix (D) is generated with $\mathrm{m}$ alternatives and $n$ criteria. Alternatives $\left(A_{i}\right)$ are placed in rows and evaluation criteria $\left(C_{j}\right)$ are placed in columns.

$$
\operatorname{Dij}=\left[\begin{array}{ccc}
a_{11} & \cdots & a_{1 n} \\
\vdots & \ddots & \vdots \\
a_{m 1} & \cdots & a_{m n}
\end{array}\right] .
$$

Step 2: A normalized decision matrix (R) is generated through the following formula.

$$
r_{i j}=\frac{a_{i j}}{\sqrt{\sum_{k=1}^{m} a_{k j}^{2}}} .
$$

Then the R matrix is obtained.

$$
\operatorname{Rij}=\left[\begin{array}{ccc}
r_{11} & \cdots & r_{1 n} \\
\vdots & \ddots & \vdots \\
r_{m 1} & \cdots & r_{m n}
\end{array}\right]
$$

Step 3: Weighted normalized decision matrix (V) is constructed.

Firstly, weights for each criterion are decided $\left(\mathrm{w}_{\mathrm{j}}\right.$, $j=1 \ldots n$ ). Then each column of $R$ matrix is multiplied by relevant $w_{j}$ value and $V$ matrix is obtained.

$$
\mathrm{Vij}=\left[\begin{array}{ccc}
w_{1} r_{11} & \cdots & w_{n} r_{1 n} \\
\vdots & \ddots & \vdots \\
w_{1} r_{m 1} & \cdots & w_{n} r_{m n}
\end{array}\right]
$$

Step 4: Ideal $\left(\mathrm{A}^{*}\right)$ and negative ideal $\left(\mathrm{A}^{-}\right)$solutions are determined. Following formulas should be used for the solutions.

$$
\begin{aligned}
& A^{*}=\left\{\left(\max _{i} v_{i j} \mid j \in J\right),\left(\min _{i} v_{i j} \mid j \in J^{\prime}\right)\right\}, \\
& A^{-}=\left\{\left(\min _{i} v_{i j} \mid j \in J\right),\left(\max _{i} v_{i j} \mid j \in J^{\prime}\right)\right\} .
\end{aligned}
$$

Step 5: Separation measures are calculated for each alternative.

Separation from the ideal alternative can be calculated through following formula. 
Eskişehir Osmangazi Üniversitesi Mühendislik ve Mimarlık Fakültesi Dergisi 27(2), 116 - 124, 2019

$S_{i}^{*}=\sum_{j=1}^{n}\left(v_{i j}-v_{j}^{*}\right)^{2}$.

Separation from the negative ideal alternative can be calculated with the formula presented below.

$S_{i}^{-}=\sum_{j=1}^{n}\left(v_{i j}-v_{j}^{-}\right)^{2}$.

Step 6: Relative closeness to ideal solution $\left(C_{i}^{*}\right)$ is calculated through the following formula. $C_{i}^{*}$ is a value which is between $0-1$ and the alternative with the $C_{i}^{*}$ value closest to 1 should be picked as the best option.

$C_{i}^{*}=\frac{S_{i}^{-}}{S_{i}^{-}+S_{i}^{*}}$.

Following section, includes an extended version of TOPSIS and its decision matrices.

\section{Expert Centered Approach: Fuzzy TOPSIS}

TOPSIS is a method, which is able to consider various criteria to evaluate alternatives in various areas. However, the determination of the weight of the different criteria is a critical process to get more realistic results. At this point, it has been decided to use Fuzzy TOPSIS to achieve a more precise approach. Consequently, it became possible to use advantages of TOPSIS with a stronger and more objective weighting process.

Fuzzy TOPSIS method uses fuzzy numbers to decide the weight of the criteria and values of each criterion for each alternative. In this study, we used triangular fuzzy numbers in the weighting and decision-making stages of the performance scores of alternatives, similar to the various researchers (Chen et al., 2006; Sun and Lin, 2009).

Heuristic evaluation is a common approach in evaluating the usability of websites. Although the criteria determined differ, it is common to see that intuitive assessments should be performed by experts. At this point, it is necessary for experts to score on verbal expressions. This brings along the fuzzy approach as a strong alternative in order to increase the reliability of the opinions. In the preference of TOPSIS method, the following advantages emphasized by Shih, Syur and Lee (2007) were considered.

- A sound logic that embodies the rationale of human choice,

- A simple computation process that can be easily programmed into a spreadsheet,

- A scalar value that accounts for the best and worst alternative at the same time.
Journal of Engineering and Architecture Faculty of Eskisehir Osmangazi University 27(2), 116 - 124, 2019

In this study, seven experts (two web designers, five academicians who have studies about web site ergonomics and usability) got involved to decide importance degrees of criteria which are proposed by Lee and Kozar (2012), presented in Table 1 and performance ratings of alternatives $\left(A_{1}, A_{2}, A_{3}\right)$. While experts were identified, there was one strict requirement for recruitment. All the experts are needed to be either worked in an e-commerce website design process or reviewed an e-commerce website through user tests at least once. After deciding the experts, they were asked to assess the degree of importance of the usability criteria specified through the evaluation forms submitted to them through the Likert scale established by the verbal expressions. The experts were also asked to evaluate the three websites subject to the study through the relevant criteria and another Likert scale prepared by verbal expressions again.

Table 1

E-Commerce Websites Usability Criteria

\begin{tabular}{ll}
\hline No & Criteria \\
\hline $\mathrm{C}_{1}$ & Consistency \\
$\mathrm{C}_{2}$ & Navigability \\
$\mathrm{C}_{3}$ & Supportability \\
$\mathrm{C}_{4}$ & Learnability \\
$\mathrm{C}_{5}$ & Simplicity \\
$\mathrm{C}_{6}$ & Interactivity \\
$\mathrm{C}_{7}$ & Telepresence \\
$\mathrm{C}_{8}$ & Credibility \\
$\mathrm{C}_{9}$ & Content relevance \\
$\mathrm{C}_{10}$ & Readability \\
\hline
\end{tabular}

Following steps, which are suggested by several studies (Alptekin et al., 2015; Nagpal et al., 2015; Şengül, Eren, Shiraz, Gezder and Şengül, 2015), were traced to apply fuzzy TOPSIS as an approach owning experts' point of view.

Step 1: Weights of criteria were decided by $\mathrm{K}$ decision makers. They used the linguistic scales which are presented in Table 2 for evaluation (Sun and Lin, 2009).

Table 2

Linguistic Evaluation Table for Importance of Criteria

\begin{tabular}{cc}
\hline Linguistic Variable & Triangular Fuzzy Number \\
\hline Very Low & $(0.0,0.1,0.3)$ \\
Low & $(0.1,0.3,0.5)$ \\
Medium & $(0.3,0.5,0.7)$ \\
High & $(0.5,0.7,0.9)$ \\
Very High & $(0.7,0.9,1.0)$ \\
\hline
\end{tabular}


Eskişehir Osmangazi Üniversitesi Mühendislik ve Mimarlık Fakültesi Dergisi 27(2), 116 - 124, 2019

Based on evaluations of $\mathrm{K}$ experts one triangular weight was calculated for each criteria via the formula presented below.

$$
\widetilde{w}_{j}=\frac{1}{K}\left[\widetilde{w}_{j}^{1}+\widetilde{w}_{j}^{2}+\cdots+\widetilde{w}_{j}^{k}\right],
$$

where $\widetilde{w}_{j}^{k}$, the importance degree of criterion $\mathrm{Cj}$ is evaluated by the expert $\mathrm{k}$. Table 3 shows the weights of criteria decided by 7 experts.

Table 3

Weights of Criteria

\begin{tabular}{ll}
\hline $\mathrm{C}_{1}$ & $(0.53,0.73,0.89)$ \\
$\mathrm{C}_{2}$ & $(0.47,0.61,0.76)$ \\
$\mathrm{C}_{3}$ & $(0.50,0.70,0.87)$ \\
$\mathrm{C}_{4}$ & $(0.40,0.59,0.76)$ \\
$\mathrm{C}_{5}$ & $(0.56,0.76,0.91)$ \\
$\mathrm{C}_{6}$ & $(0.44,0.64,0.83)$ \\
$\mathrm{C}_{7}$ & $(0.36,0.56,0.73)$ \\
$\mathrm{C}_{8}$ & $(0.67,0.87,0.99)$ \\
$\mathrm{C}_{9}$ & $(0.59,0.79,0.94)$ \\
$\mathrm{C}_{10}$ & $(0.47,0.67,0.84)$ \\
\hline
\end{tabular}

Step 2: Alternatives were evaluated for each criteria through linguistic scale which is presented at Table 4 (Sun and Lin, 2009).

Table 4

Linguistic Evaluation Table for Performances of Alternatives

\begin{tabular}{cc} 
Linguistic Variable & Triangular Fuzzy Number \\
\hline Very Poor & $(0,1,3)$ \\
Poor & $(1,3,5)$ \\
Fair & $(3,5,7)$ \\
Good & $(5,7,9)$ \\
Very Good & $(7,9,10)$ \\
\hline
\end{tabular}

Based on evaluations of $\mathrm{K}$ experts, one triangular performance rating was calculated for each alternative via the formula presented below.

$$
\tilde{x}_{i j}=\frac{1}{K}\left[\tilde{x}_{i j}^{1}+\tilde{x}_{i j}^{2}+\cdots+\tilde{x}_{i j}^{k}\right]
$$

where $\tilde{x}_{i j}^{k}$ is the rating of alternative $A_{i}$ with respect to criteria $C_{j}$ decided by the expert $\mathrm{k}$. Table 5 shows the performance ratings of alternatives based on expert evaluations.

Table 5.
Journal of Engineering and Architecture Faculty of Eskisehir Osmangazi University 27(2), 116 - 124, 2019

Performance Evaluations of Alternatives with Triangular Fuzzy Numbers

\begin{tabular}{llllllllll}
\hline & \multicolumn{3}{c}{$\mathrm{A} 1$} & \multicolumn{3}{c}{$\mathrm{A} 2$} & & $\mathrm{~A} 3$ \\
\hline $\mathrm{C} 1$ & 3.6 & 5.6 & 7.4 & 5.9 & 7.9 & 9.4 & 3.6 & 5.6 & 7.4 \\
C2 & 4.1 & 6.1 & 8.0 & 6.1 & 8.1 & 9.6 & 4.1 & 6.1 & 8.0 \\
C3 & 3.4 & 5.3 & 7.1 & 4.1 & 6.1 & 8.1 & 2.0 & 3.9 & 5.9 \\
C4 & 3.1 & 5.0 & 7.0 & 5.3 & 7.3 & 9.0 & 3.0 & 5.0 & 7.0 \\
C5 & 4.1 & 6.1 & 7.9 & 5.6 & 7.6 & 9.0 & 2.6 & 4.4 & 6.4 \\
C6 & 3.7 & 5.6 & 7.4 & 5.0 & 7.0 & 8.9 & 3.3 & 5.3 & 7.3 \\
C7 & 3.1 & 5.0 & 6.9 & 4.7 & 6.7 & 8.4 & 2.9 & 4.7 & 6.7 \\
C8 & 3.9 & 5.4 & 6.7 & 6.1 & 8.1 & 9.6 & 2.3 & 4.1 & 6.1 \\
C9 & 3.9 & 5.9 & 7.9 & 6.1 & 8.1 & 9.6 & 3.6 & 5.6 & 7.6 \\
C10 & 4.4 & 6.4 & 8.1 & 6.1 & 8.1 & 9.6 & 3.0 & 5.0 & 7.0 \\
\hline
\end{tabular}

Step 3: Fuzzy decision matrix was normalized. Normalized fuzzy decision matrix is denoted by $\tilde{R}$.

$$
\tilde{R}=\left[\tilde{r}_{i j}\right]_{m \times n}, i=1 \ldots m, j=1 \ldots n .
$$

Then normalization process was performed using formula presented below and Table 6 shows the normalized decision matrix.

$$
\widetilde{r}_{i j}=\left(\frac{a_{i j}}{c_{j}^{*}}, \frac{b_{i j}}{c_{j}^{*}}, \frac{c_{i j}}{c_{j}^{*}}\right), \quad c_{j}^{*}=\max _{i} c_{i j} .
$$

Table 6

Normalized Fuzzy Decision Matrix

\begin{tabular}{cccccccccc}
\hline & \multicolumn{3}{c}{ A1 } & \multicolumn{9}{c}{ A2 } & & & A3 & \\
\hline C1 & 0.38 & 0.59 & 0.79 & 0.62 & 0.83 & 1 & 0.38 & 0.59 & 0.79 \\
C2 & 0.43 & 0.64 & 0.84 & 0.64 & 0.85 & 1 & 0.43 & 0.64 & 0.84 \\
C3 & 0.42 & 0.65 & 0.88 & 0.51 & 0.75 & 1 & 0.25 & 0.47 & 0.72 \\
C4 & 0.35 & 0.56 & 0.78 & 0.59 & 0.81 & 1 & 0.33 & 0.56 & 0.78 \\
C5 & 0.46 & 0.68 & 0.87 & 0.62 & 0.84 & 1 & 0.29 & 0.49 & 0.71 \\
C6 & 0.42 & 0.63 & 0.84 & 0.56 & 0.79 & 1 & 0.37 & 0.6 & 0.82 \\
C7 & 0.37 & 0.59 & 0.81 & 0.56 & 0.8 & 1 & 0.34 & 0.56 & 0.8 \\
C8 & 0.4 & 0.57 & 0.7 & 0.64 & 0.85 & 1 & 0.24 & 0.43 & 0.64 \\
C9 & 0.4 & 0.61 & 0.82 & 0.64 & 0.85 & 1 & 0.37 & 0.58 & 0.79 \\
C10 & 0.46 & 0.67 & 0.85 & 0.64 & 0.85 & 1 & 0.31 & 0.52 & 0.73 \\
\hline
\end{tabular}

Step 4: Weighted normalized fuzzy decision matrix was constructed. It is denoted by $\tilde{V}$.

$$
\tilde{V}=\left[\tilde{v}_{i j}\right]_{m \times n}, i=1 \ldots m, j=1 \ldots n,
$$


Eskişehir Osmangazi Üniversitesi Mühendislik ve Mimarlık Fakültesi Dergisi 27(2), 116 - 124, 2019

$$
\tilde{v}_{i j}=\tilde{r}_{i j}(\cdot) \widetilde{w}_{j}
$$

Table 7 shows the weighted normalized decision matrix.

Table 7

Weighted Normalized Fuzzy Decision Matrix

\begin{tabular}{ccccccccccc}
\hline \multicolumn{9}{c}{ A1 } & \multicolumn{7}{c}{ A2 } & \multicolumn{3}{c}{ A3 } \\
\hline C1 & 0.2 & 0.43 & 0.7 & 0.33 & 0.6 & 0.89 & 0.2 & 0.43 & 0.7 \\
C2 & 0.2 & 0.39 & 0.64 & 0.3 & 0.52 & 0.76 & 0.2 & 0.39 & 0.64 \\
C3 & 0.21 & 0.46 & 0.77 & 0.26 & 0.53 & 0.87 & 0.13 & 0.33 & 0.63 \\
C4 & 0.14 & 0.33 & 0.59 & 0.24 & 0.47 & 0.76 & 0.13 & 0.33 & 0.59 \\
C5 & 0.26 & 0.51 & 0.8 & 0.35 & 0.64 & 0.91 & 0.16 & 0.37 & 0.65 \\
C6 & 0.19 & 0.41 & 0.7 & 0.25 & 0.51 & 0.83 & 0.16 & 0.39 & 0.68 \\
C7 & 0.13 & 0.33 & 0.59 & 0.2 & 0.45 & 0.73 & 0.12 & 0.31 & 0.58 \\
C8 & 0.27 & 0.5 & 0.69 & 0.43 & 0.74 & 0.99 & 0.16 & 0.37 & 0.63 \\
C9 & 0.23 & 0.48 & 0.77 & 0.37 & 0.67 & 0.94 & 0.22 & 0.46 & 0.74 \\
C10 & 0.22 & 0.45 & 0.72 & 0.3 & 0.57 & 0.84 & 0.15 & 0.35 & 0.62 \\
\hline
\end{tabular}

Step 5: Fuzzy positive ideal solution (FPIS) and fuzzy negative ideal solution (FNIS) are determined and the distance of each alternative form FPIS and FNIS are calculated. Since all elements of weighted normalized fuzzy decision matrix are in the range [0-1], it is possible to define FPIS $\left(A^{*}\right)$ and FNIS $\left(A^{-}\right)$with the following formulas $(13,14)$.

$$
\begin{aligned}
& A^{*}=\left(\tilde{v}_{1}^{*}, \tilde{v}_{2}^{*}, \ldots, \tilde{v}_{n}^{*}\right), \\
& A^{-}=\left(\tilde{v}_{1}^{-}, \tilde{v}_{2}^{-}, \ldots, \tilde{v}_{n}^{-}\right),
\end{aligned}
$$

where $\tilde{v}_{1}^{*}=(1,1,1)$ and $\tilde{v}_{1}^{-}=(0,0,0), \mathrm{j}=1,2, \ldots, \mathrm{n}$.

Distances between triangular fuzzy numbers were calculated via vertex method. According to this method the following formula should be used (15).

$$
\sqrt{\frac{1}{3}\left[\left(m_{1}-n_{1}\right)^{2}+\left(m_{1}-n_{1}\right)^{2}+\left(m_{1}-n_{1}\right)^{2}\right]}
$$

To find the distances $\left(d^{*}\right.$ and $\left.d^{-}\right)$of each alternative from $A^{*}$ and from $A^{-}$following formulas were used (16, $17)$ and the finalized calculations are located at Table 8.

$$
d_{i}^{*}=\sum_{j=1}^{n} d\left(\tilde{v}_{i j}, \tilde{v}_{j}^{*}\right), \quad i=1,2, \ldots, m
$$

Journal of Engineering and Architecture Faculty of Eskisehir Osmangazi University 27(2), 116 - 124, 2019

$$
d_{i}^{-}=\sum_{j=1}^{n} d\left(\tilde{v}_{i j}, \tilde{v}_{j}^{-}\right), \quad i=1,2, \ldots, m
$$

Table 8

Distances Values of Alternatives

\begin{tabular}{ccc}
\hline Alternatives & $d_{i}^{*}$ & $d_{i}^{-}$ \\
\hline $\mathrm{A}_{1}$ & 5.93 & 4.87 \\
$\mathrm{~A}_{2}$ & 4.83 & 6.18 \\
$\mathrm{~A}_{3}$ & 6.38 & 4.41 \\
\hline
\end{tabular}

Step 6: The closeness coefficients were calculated with the formula presented below (18).

$$
C C_{i}=\frac{d_{i}^{-}}{d_{i}^{-}+d_{i}^{+}} .
$$

The closeness coefficients of alternatives are presented in Table 9.

Table 9

Closeness Coefficients

\begin{tabular}{ccc}
\hline & $\mathrm{CC}_{\mathrm{i}}$ & Rank \\
\hline $\mathrm{A}_{1}$ & 0.45 & 2 \\
$\mathrm{~A}_{2}$ & 0.56 & 1 \\
$\mathrm{~A}_{3}$ & 0.41 & 3 \\
\hline
\end{tabular}

As a result, a ranking was obtained based on experts' point of view and ten pre-determined usability criteria. According to the experts, alternative 2 is the most usable and alternative 3 is the least usable e-commerce websites. According to the experts, the most important three usability criteria are credibility, content relevance and simplicity, respectively. On the other hand, the least important usability criteria is telepresence. This result shows how three websites were evaluated by experts based on their point of views, expertise and ten predetermined usability criteria. However, some other approach is needed to see whether the usability understanding of the users is consistent with experts. That's why users will be placed at the center of evaluation process instead of experts at the next step. 
Eskişehir Osmangazi Üniversitesi Mühendislik ve Mimarlık Fakültesi Dergisi 27(2), 116 - 124, 2019

\section{User Centered Approach: Survey Based Criteria Weighting for TOPSIS}

\subsection{Survey Study and Descriptive Statistics}

The survey conducted among 179 websites users who made at least one online purchase from at least one of the websites before scored the factors for that website. Survey respondents were recruited via online notices, emails, and social media channels. In the survey, participants were asked whether they had ever used any of the websites subject to study, before starting the evaluation. Participants are required to evaluate the websites they have used at least once, and if they have used more than one site, they were asked to evaluate the one they used the most recently. Some additional information was collected through the questions below:

-What products did you buy from the internet in the last year?

-Have you ordered from e-commerce sites about 40 times so far?

-How long are you using the internet?

The average survey completion time was approximately 30 mins and online surveys were active for 3 weeks. Participants were asked to rate the importance levels of the criteria besides usability evaluations of three websites. For this purpose, links to the websites were also attached to the surveys. Google Forms platform were used to prepare and share the surveys. Common website usability factors (Table 1) with 7-likert scale, which are integrated from the past studies and proposed by Lee and Kozar (2012), are used to conduct our survey study. Demographics found at the Table 10.

Table 10

Demographics

\begin{tabular}{ll}
\hline Category & Statistic \\
\hline Gender (female) & $48 \%$ \\
Average age & 26.30 years $\sigma=4.72$ \\
Average internet using & 11.08 years $\sigma=2.91$ \\
Average internet using ability & 4.12 years $\sigma=0.79$ \\
Average online purchases & 11.78 times $\sigma=5.30$ \\
\hline
\end{tabular}

Cronbach's Alpha Reliability is 0.904 for websites usability criteria. After the reliability test results, we conducted a factor analysis for these three websites for the usability criteria. Analyses results suggest only a
Journal of Engineering and Architecture Faculty of Eskisehir Osmangazi University 27(2), 116 - 124, 2019

single factor, since these criteria give similar interpretations.

\subsection{TOPSIS with Weighted Regression Estimates}

The sub goal of this study is to use survey evaluations mentioned previously to rank alternatives with the same criteria. Besides expert evaluations, user satisfaction is also crucial for the online purchases, in fact, they are thought as complementary. At this part of the study, the steps of TOPSIS method are applied one more time with the weighted regression estimates. Since regression estimates are obtained by minimizing the sum of squares of residuals and they give unbiased predictions, we prefer to use regression based weights. Also, it is well known that regression parameter estimates for $\beta(\hat{\beta})$ show the degree of dependent and independent variables relations, so that implies a conceptual logic for the analyses (Gelman and Hill, 2009). In multi-criteria decision making approaches, different methods can be used to determine the importance of the criteria. In the case of a user-oriented assessment, the number of participants should be higher, and a weight parameter representing the relationship among variables should be used. This requirement brought about the preference for using regression in the study for the first time, according to our best knowledge.

User evaluations about the alternatives were collected through the conducted survey which has questions based on criteria presented in Table 1. Then decision matrix was constructed with these user evaluations (Table 11).

Weighted regression estimates are implemented by using generalized least squares and the weights are located at Table 12 . While deciding weights of the criteria, weighted regression estimate values were considered as the importance of criteria via the following formula (19).

$$
w_{j}=\frac{e_{j}}{\sum_{j=1}^{n} e_{j}},
$$

where $e_{j}$ is the weighted regression estimate value of the relevant criteria. 
Eskişehir Osmangazi Üniversitesi Mühendislik ve Mimarlık Fakültesi Dergisi 27(2), 116 - 124, 2019

Table 11

Decision Matrix

\begin{tabular}{llll}
\hline & A1 & A2 & A3 \\
\hline C1 & 5.02 & 5.27 & 5.18 \\
C2 & 4.98 & 5.44 & 5.22 \\
C3 & 4.51 & 4.78 & 4.77 \\
C4 & 5.08 & 5.2 & 5.11 \\
C5 & 4.28 & 4.58 & 4.94 \\
C6 & 4.66 & 5.14 & 4.91 \\
C7 & 4.09 & 4.97 & 5 \\
C8 & 5.02 & 5.62 & 5.28 \\
C9 & 4.94 & 5.25 & 5.4 \\
C10 & 5.08 & 5.57 & 4.97 \\
\hline
\end{tabular}

Table 12

Weights of Criteria

\begin{tabular}{rrrrr}
\hline $\mathrm{C} 1$ & $\mathrm{C} 2$ & $\mathrm{C} 3$ & $\mathrm{C} 4$ & $\mathrm{C} 5$ \\
\hline 0.094 & 0.102 & 0.089 & 0.103 & 0.099 \\
\hline $\mathrm{C} 6$ & $\mathrm{C} 7$ & $\mathrm{C} 8$ & $\mathrm{C} 9$ & $\mathrm{C} 10$ \\
\hline 0.106 & 0.097 & 0.108 & 0.096 & 0.106 \\
\hline
\end{tabular}

After this step, the remaining steps of the TOPSIS method were applied to obtain the closeness coefficients. According to the User Centered Approach's results; alternative 1 was ranked $3\left(\mathrm{CC}_{\mathrm{i}}=0.06\right)$, alternative $2\left(\mathrm{CC}_{\mathrm{i}}=0.77\right)$, and alternative $3\left(\mathrm{CC}_{\mathrm{i}}=0.63\right)$, were ranked 1 and 2, respectively. This ranking shows that users and experts agree on that the alternative 2 is the most usable e-commerce website. However, they have different ideas about alternative 3 and alternative 1. Users think that alternative 3 is better than alternative 1 while the experts think the exact opposite. To better understand the different rankings, it is crucial to investigate the importance levels of the usability criteria. According to the users, the most important three usability criteria are credibility, interactivity and readability, respectively. On the other hand, the least important usability criteria is supportability. This criteria importance evaluation shows a huge difference compare to the experts' point of view. They only share the same idea about the most important usability criteria (credibility). While users consider interactivity and readability as very important usability components, experts think that content relevance and simplicity are more important. Similarly, the users do not agree with
Journal of Engineering and Architecture Faculty of Eskisehir Osmangazi University 27(2), 116 - 124, 2019

the experts about supportability. Experts' ranked supportability as the fifth most important criteria but users consider it as the least important one.

\section{Conclusion}

In this study, fuzzy TOPSIS and also regression weights for TOPSIS are used to rank websites. The methods used for weighting are more useful in manner of being objective. According to the closeness coefficients of two TOPSIS approaches, the second alternative is always the number one, while the first and the third alternative's places are changeable in two methods. Ranking changes between the first and the third alternatives can be evaluated in terms of the differences between designers' and customers' behaviors. Different expectations and different senses of criteria weighting cause a differentiation on rankings.

Assessing expert opinions in usability studies using the Fuzzy TOPSIS method has recently become an interesting topic. It is the strong aspect of this method that many different criteria can be taken into account and a ranking can be achieved by evaluating on the same scale. On the other hand, usability cannot be evaluated only by the designer or the expert, and the optimum result cannot be achieved. Therefore, user tests are also needed. As an alternative to user tests, which are mostly done in scenario-based and controlled environments, it is possible to suggest a user-centered approach for TOPSIS that makes it possible to reach more participants and overcome the weighting step through statistical methods. The two approaches suggested different ranking results for the same websites. This situation indicates different expectations for usability between experts and simple users for such sites. It is anticipated that taking into account both approaches' usability ranking results such as this study can play a critical role to enhance the satisfaction of potential customers of that kind of websites. From this point, it can be possible to generate new, structured and comparative usability surveys and evaluation tools focusing on e-commerce website usability. The detection of design problems may become more appropriate and consequently, user testing processes and design iterations can be made more effectively.

The way of gathering survey results of this study may be improved by recruiting experts and users in a particular time and environment instead of an online platform. Interacting with users and experts from several backgrounds would decrease the online platform limitations.

Since information technologies and also online shopping is gradually changing, this type of work always crucial for firms to hold themselves in the game. This study is limited with three online shopping websites in Turkey. 
Eskişehir Osmangazi Üniversitesi Mühendislik ve Mimarlık Fakültesi Dergisi 27(2), 116 - 124, 2019

However, it can easily be applied in other industries such as telecommunication, education, finance, etc. As a future study, different type of websites will be evaluated through more specific usability criteria besides user tests and eye tracker data. IBM Computer System Usability Questionnaire (CSUQ) and Technology Acceptance Model (TAM) will be considered as supportive tools, as well.

This study was not out of any limitations. Although the Cronbach alpha score indicates the user survey was reliable, different usability criteria and diverse user population may change the results. On the other hand, various ways for fuzzy approach and calculation methods of evaluations results such as the use of geometric mean, mod, or median may also cause different rankings. From this point, they will also be considered as future works for comparisons, to change the usability criteria, to use different fuzzy logic methods, and to try different calculation approach of evaluations.

\section{Conflict of Interest}

No conflict of interest was declared by the authors.

\section{References}

Akincilar, A., \& Dagdeviren, M. (2014). A hybrid multicriteria decision making model to evaluate hotel websites. International Journal of Hospitality Management, 36, 263-271. doi: https://doi.org/10.1016/j.ijhm.2013.10.002

Alptekin, N., Hall, E. E., \& Sevim, N. (2015). Evaluation of Websites Quality Using Fuzzy TOPSIS Method. International Journal of Academic Research in Business and Social Sciences, 5(8), 221-242. doi: https://doi.org/10.6007/ijarbss/v5-i8/1778

Belanche, D., Casaló, L. V., \& Guinalíu, M. (2012). Website usability, consumer satisfaction and the intention to use a website: The moderating effect of perceived risk. Journal of Retailing and Consumer Services,19(1), 124-132. doi: https://doi.org/10.1016/i.jretconser.2011.11.001

Boran, F. E., Genç, S., Kurt, M., \& Akay, D. (2009). A multi-criteria intuitionistic fuzzy group decision making for supplier selection with TOPSIS method. Expert Systems with Applications, 36(8), 1136311368.

doi: https://doi.org/10.1016/j.eswa.2009.03.039

Carmona, C. J., Ramírez-Gallego, S., Torres, F., Bernal, E., del Jesus, M. J., \& García, S. (2012). Web usage mining to improve the design of an e-commerce website: OrOliveSur. com. Expert Systems with Applications,
Journal of Engineering and Architecture Faculty of Eskisehir Osmangazi University 27(2), 116 - 124, 2019

$\begin{array}{lc}\text { 39(12), } & \text { 11243-11249. } \\ \text { https://doi.org/10.1016/j.eswa.2012.03.046 }\end{array}$

Chen CT (2000). Extension of the TOPSIS for group decision making under fuzzy Environment. Fuzzy Sets and Systems,114(1):1-9. doi: https://doi.org/10.1016/S0165-0114(97)00377-1

Chen, C. T., Lin, C. T., \& Huang, S. F. (2006). A fuzzy approach for supplier evaluation and selection in supply chain management. International journal of production economics, 102(2), 289-301. doi: https://doi.org/10.1016/j.ijpe.2005.03.009

Davidavičienė, V., \& Tolvaišas, J. (2011). Measuring quality of e-commerce web sites: Case of lithuania. Economics and Management, 16, 723-729. Retrieved from: https://etalpykla.lituanistikadb.lt

De Jong, M., \& Lentz, L. (2006). Scenario evaluation of municipal Web sites: Development and use of an expert-focused evaluation tool. Government Information Quarterly, 23(2), 191-206. doi: https://doi.org/10.1016/i.giq.2005.11.007

Delice, E. K., \& Güngör, Z. (2009). The usability analysis with heuristic evaluation and analytic hierarchy process. International Journal of Industrial Ergonomics, 39(6), 934-939. doi: https://doi.org/10.1016/j.ergon.2009.08.005

Gelman, A. \& Hill, J. (2009). Data Analysis Using Regression and Multilevel/Hierarchical Models. Cambridge University Press, NY, USA.

Goh, K. N., Chen, Y. Y., Lai, F. W., Daud, S. C., Sivaji, A., \& Soo, S. T. (2013). A Comparison of Usability Testing Methods for an E-Commerce Website: A Case Study on a Malaysia Online Gift Shop. Information Technology: New Generations (ITNG), 143-150, Las Vegas, USA.

Guo, M., \& Zhang, Y. B. (2010). A stock selection model based on analytic hierarchy process, factor analysis and TOPSIS. Computer and communication technologies in agriculture engineering (CCTAE), 466-469.

Huang, J. (2008). Combining entropy weight and TOPSIS method for information system selection. Cybernetics and Intelligent Systems, 1281-1284. doi: https://doi.org/10.1109/ICCIS.2008.4670971

Hwang, C.L. \& Yoon, K. (1981). Multple Attribute Decision Making-Methods and Applications: A State-of-the-Art Survey, Springer-Verlag, New York.

Lee, S. \& Koubek, R. J. (2010). The effects of usability and web design attributes on user preference for ecommerce web sites. Computers in Industry, 61(4), 329-341.

doi: https://doi.org/10.1016/j.compind.2009.12.004 
Eskişehir Osmangazi Üniversitesi Mühendislik ve Mimarlık Fakültesi Dergisi 27(2), 116 - 124, 2019

Lee, Y. \& Kozar, K. A. (2012). Understanding of website usability: Specifying and measuring constructs and their relationships. Decision Support Systems, 52(2), 450-463.

doi: https://doi.org/10.1016/j.dss.2011.10.004

Nagpal, R., Mehrotra, D., Bhatia, P. K., \& Sharma, A. (2015). Rank university websites using fuzzy AHP and fuzzy TOPSIS approach on usability. International journal of information engineering and electronic business, 7(1), 29. doi: https://doi.org/10.5815/ijieeb.2015.01.04

Nivala, A. M., Brewster, S., \& Sarjakoski, T. L. (2008). Usability evaluation of web mapping sites. The Cartographic Journal, 45(2), 129-138. doi: https://doi.org/10.1179/174327708X305120

Pal, M. N. \& Choudhury, K. (2009). Exploring the dimensionality of service quality: an application of topsis in the Indian banking industry. Asia-Pacific Journal of Operational Research, 26(01), 115-133. doi: https://doi.org/10.1142/S0217595909002110

Shih, H. S,. Syur, H. J. \& Lee, E. S. (2007). An extension of TOPSIS for group decision making. Mathematical and Computer Modeling, 45(7-8), 801-813. doi: https://doi.org/10.1016/j.mcm.2006.03.023

Sivaji, A., Downe, A. G., Mazlan, M. F., Soo, S. T., \& Abdullah, A. (2011). Importance of incorporating fundamental usability with social \& trust elements for e-commerce website. International Conference on Business, Engineering and Industrial Applications (ICBEIA), 221-226, Kuala Lumpur, Malaysia.

Sun, C. C., \& Lin, G. T. (2009). Using fuzzy TOPSIS method for evaluating the competitive advantages of shopping websites. Expert Systems with Applications, 36(9), 11764-11771. doi: https://doi.org/10.1016/j.eswa.2009.04.017

Şengül, Ü, Eren, M., Shiraz, S. E., Gezder, V., \& Şengül, A. B. (2015). Fuzzy TOPSIS method for ranking renewable energy supply systems in Turkey. Renewable Energy, 75, 617-625. doi: https://doi.org/10.1016/j.renene.2014.10.04

Top Sites in Turkey The sites in the top sites lists are ordered by their 1 month Alexa traffic rank. Retrieved from https://www.alexa.com/topsites/countries/TR

Tracy, J. P. \& Albers, M. J. (2006). Measuring cognitive load to test the usability of web sites. Annual Conference-society for technical communication, 256261, Nevada, USA.

Turkey B2C E-Commerce Market 2017. Retrieved from https://www.ystats.com/market-reports/turkeyb2c-e-commerce-market-2017-2/
Journal of Engineering and Architecture Faculty of Eskisehir Osmangazi University 27(2), 116 - 124, 2019

Turkey B2C E-Commerce Market 2016, yStats.com. (n.d.). Retrieved from https://www.ystats.com/ market-reports/turkey-b2c-e-commerce-market$2016 /$

Youngblood, N. E., \& Mackiewicz, J. (2012). A usability analysis of municipal government website home pages in Alabama. Government Information Quarterly, 29(4), 582-588.

Yu, X., Guo, S., Guo, J. \& Huang, X. (2011). Rank B2C ecommerce websites in e-alliance based on AHP and fuzzy TOPSIS. Expert Systems with Applications, 38(4), 3550-3557. doi: https://doi.org/10.1016/j.eswa.2010.08.143

Yue, Z. (2011). An extended TOPSIS for determining weights of decision makers with interval numbers. Knowledge-Based Systems, 24(1), 146-153. doi: https://doi.org/10.1016/j.giq.2011.12.010

Zadeh, L. A. (1965). Fuzzy Sets. Information and Control 8 (3) 338- 356. doi: https://doi.org/10.1016/S00199958(65)90241-X

Zeleny, M. (1982). Multiple Criteria Decision Making. McGraw-Hill, New York. 